\title{
Monitoring Coronavirus Disease 2019: A Review of Available Diagnostic Tools
}

\section{OPEN ACCESS}

Edited by:

Reza Lashgari,

Institute for Research in Fundamental

Sciences, Iran

Reviewed by:

Xianding Deng,

University of California, San Francisco,

United States

Kundlik Gadhave,

Johns Hopkins University,

United States

Dubravka Drabek

Erasmus Medical Center, Netherlands

${ }^{*}$ Correspondence:

Jin Wang

wjincityu@yahoo.com

Specialty section:

This article was submitted to Infectious Diseases - Surveillance

Prevention and Treatment,

a section of the journal

Frontiers in Public Health

Received: 25 February 2021

Accepted: 23 April 2021

Published: 07 June 2021

Citation:

Liu S, Li Q, Chu X, Zeng M, Liu M, He X, Zou H, Zheng J, Corpe C,

Zhang X, XU J and Wang J (2021)

Monitoring Coronavirus Disease 2019:

A Review of Available Diagnostic

Tools. Front. Public Health 9:672215.

doi: 10.3389/fpubh.2021.672215

\begin{abstract}
Shanshan Liu ${ }^{1}$, Qiuyue $\mathrm{Li}^{1}$, Xuntao Chu ${ }^{2}$, Minxia Zeng ${ }^{2}$, Mingbin Liu ${ }^{1,3}$, Xiaomeng He ${ }^{1}$, Heng Zou ${ }^{1}$, Jianghua Zheng ${ }^{4}$, Christopher Corpe ${ }^{5}$, Xiaoyan Zhang ${ }^{1}$, Jianqing $X u^{1}$ and Jin Wang ${ }^{1 *}$

${ }^{1}$ Shanghai Public Health Clinical Center, Fudan University, Shanghai, China, ${ }^{2}$ Zhuhai Livzon Diagnostics Inc., Guangdong, China, ${ }^{3}$ School of Pharmacy, Gannan Medical University, Jiangxi, China, ${ }^{4}$ Department of Laboratory Medicine, Zhoupu Hospital Affiliated to Shanghai University of Medicine and Health Sciences, Shanghai, China, ${ }^{5}$ Nutritional Science Department, King's College London, London, United Kingdom
\end{abstract}

Coronavirus disease 2019 (COVID-19) pneumonia is caused by the virus severe acute respiratory syndrome coronavirus 2 (SARS-CoV-2) and has rapidly become a global public health concern. As the new type of betacoronavirus, SARS-CoV-2 can spread across species and between populations and has a greater risk of transmission than other coronaviruses. To control the spread of SARS-CoV-2, it is vital to have a rapid and effective means of diagnosing asymptomatic SARS-CoV-2-positive individuals and patients with COVID-19, an early isolation protocol for infected individuals, and effective treatments for patients with COVID-19 pneumonia. In this review, we will summarize the novel diagnostic tools that are currently available for coronavirus, including imaging examinations and laboratory medicine by next-generation sequencing (NGS), real-time reverse transcriptase-polymerase chain reaction (rRT-PCR) analysis, immunoassay for COVID-19, cytokine and T cell immunoassays, biochemistry and microbiology laboratory parameters in the blood of the patients with COVID-19, and a field-effect transistor-based biosensor of COVID-19. Specifically, we will discuss the effective detection rate and assay time for the rRT-PCR analysis of SARS-CoV-2 and the sensitivity and specificity of different antibody detection methods, such as colloidal gold and ELISA using specimen sources obtained from the respiratory tract, peripheral serum or plasma, and other bodily fluids. Such diagnostics will help scientists and clinicians develop appropriate strategies to combat COVID-19.

Keywords: COVID-19, SARS-CoV-2, rRT-PCR, immunoassay, coronavirus

\section{INTRODUCTION}

Coronavirus $(\mathrm{CoV})$ infections in humans primarily involve the upper respiratory and gastrointestinal tracts. Infections can result in a mild self-limiting disease similar to influenza or can become more severe life-threatening bronchitis and pneumonia with kidney involvement (1). The first human coronavirus $(\mathrm{HCoV})$ was isolated from the mucus of a patient with influenza in 1965 and was known as B814 (2). Coronaviruses are enveloped viruses with a single-stranded, positive-sense RNA genome and have the largest known RNA virus genome of $\sim 26-32 \mathrm{~kb}$ (3). Open reading frame 1a (ORF1a) mainly encodes non-structural proteins, such as enzymes 
related to viral replication and transcription, and $\sim 1 / 4$ of the genes at the $3^{\prime}$ end mainly encode surface spike (S) protein, membrane $(\mathrm{M})$ protein, small envelope membrane $(\mathrm{E})$ protein, and nucleocapsid (N) protein (4). Six coronaviruses are known to cause human diseases, including two members of the genus Alphacoronavirus HCoV-229E and HCoV-OC43 and four members of the genus Betacoronavirus HCoV-NL63, HCoV-HKU1, severe acute respiratory syndrome coronavirus (SARS-CoV), and Middle East respiratory syndrome coronavirus (MERS-CoV) (5). MERS-CoV is the pathogen that led to the outbreak of severe respiratory diseases in the Middle East in 2012 (6), and SARS-CoV is the cause of SARS in Guangdong Province of China in 2002 and 2003 (7-9).

A novel Betacoronavirus, SARS-CoV-2, that causes coronavirus disease 2019 (COVID-19) was first identified amid an outbreak of respiratory illness in Wuhan and named by the World Health Organization (WHO) on February 11, 2020 (10). Chan et al. (11) analyzed a family cluster of six people who returned to their homes in Shenzhen with infections after traveling to Wuhan, China. The incubation periods, clinical manifestations, and laboratory and radiological information of these patients with COVID-19 and the possible infection route of SARS-CoV-2 have been analyzed (12). Most patients presented with fever, dry cough, dyspnea, and computed tomography (CT) chest scans that revealed bilateral ground-glass opacities (GGOs). However, the characteristics of SARS-CoV-2 infection have few similarities to those of SARS-CoV and MERS-CoV infections $(13,14)$. Along with MERS-CoV and SARS-CoV, as the seventh member of the coronavirus family that infects humans, SARS-CoV-2 is more closely related to batSL-CoVZC45 and bat-SL-CoVZXC21 (15). At the cellular level, angiotensin-converting enzyme II (ACE2) is the receptor used by SARS-CoV-2 (16). Similar to SARS-CoV infection, SARS-CoV-2 enters cells through the receptor ACE2 and activates its spike protein through TMPRSS2 $(17,18)$. However, SARS-CoV-2 infections may be combined with a superspreader event under certain circumstances and transmitted on a large scale (19); this poses a high risk at the population level and will cause disruptions to the global public health system and economic losses (19). Thus, better methods for the early detection of this novel coronavirus are urgently needed.

In clinical analysis laboratories around the world, real-time reverse transcriptase-polymerase chain reaction (rRT-PCR) is commonly used as an early detection method of the SARS-CoV2 virus. rRT-PCR has several advantages, including reliability and high specificity, although analysis can take a long time, require expensive equipment, and produce quite variable false-negative rates (20). Immunoassays are a rapid bioanalytical method to detect an antigen-antibody that are widely used and take only about $20 \mathrm{~min}$ to give results, but immunoassays are not as specific as the tests recognizing viral RNA sequences, and during the early stages of infection may produce false-negative results (21). All the currently available diagnostic methods with their advantages and disadvantages are shown in Figure 1. Imaging examination is also a quick and sensitive diagnosis for COVID-19 in the early period, but it should be combined with other laboratory tests to improve its accuracy.

\section{IMAGING EXAMINATIONS FOR THE EARLY SCREENING OF CORONAVIRUS DISEASE 2019}

The imaging manifestations of COVID-19 on CT are similar to those of many other viral pneumonias, such as influenza, respiratory syncytial virus, and adenovirus infection, which make

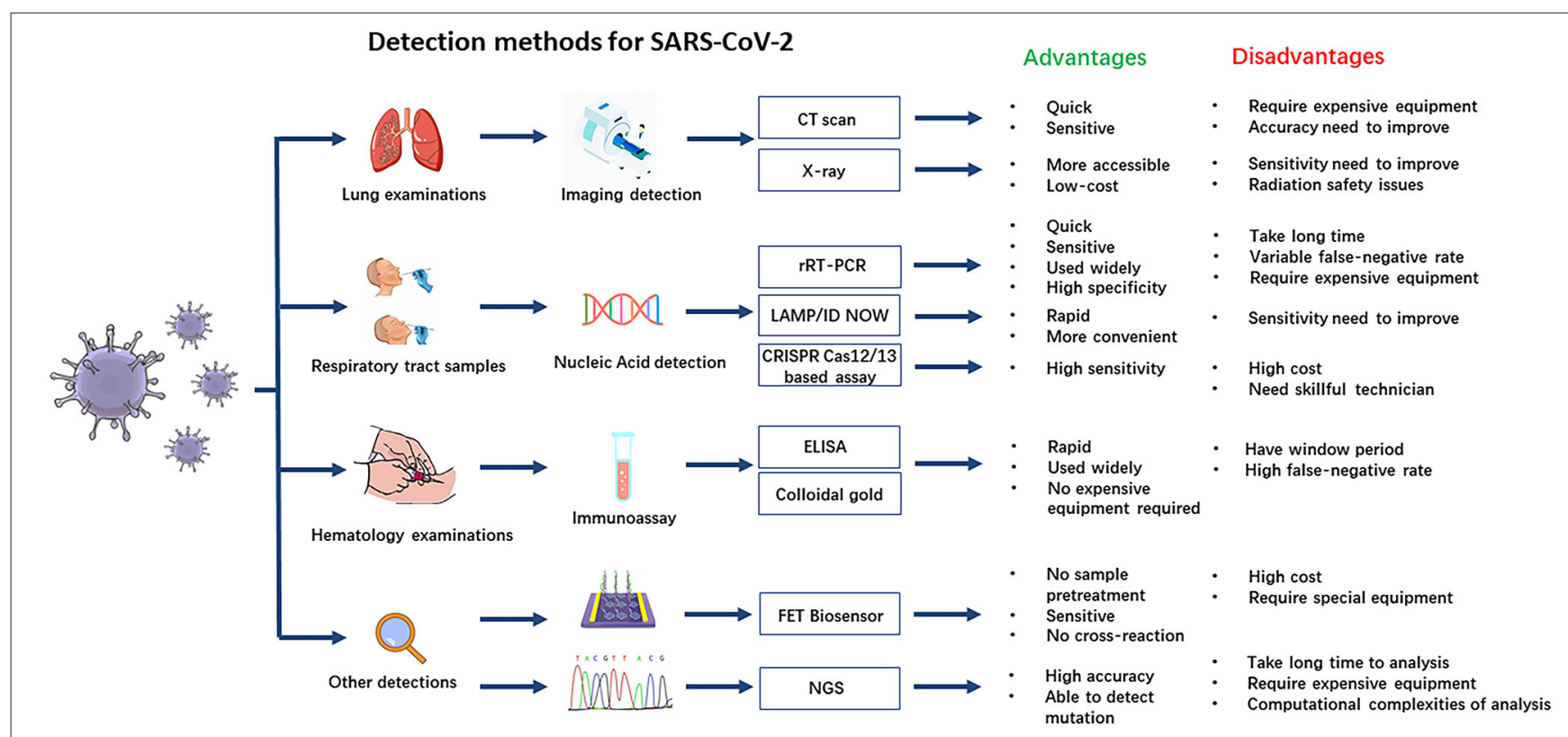

FIGURE 1 | The detection methods for severe acute respiratory syndrome coronavirus 2 (SARS-CoV-2). 
a differential diagnosis for COVID-19 difficult. For example, CT images in patients with SARS may show extensive disease and airspace consolidation (22), and MERS pneumonia appears on CT images as subpleural and basal airspace lesions with extensive GGOs and consolidation (23). Although the CT manifestations of COVID-19 have some similarities with those of MERS and SARS, CT is more sensitive for early stages of diseases (22), which still has a certain practicality when used for the early screening of COVID-19. The most common patterns of COVID19 on thin-section CT images are pure GGOs that were defined as a hazy increase in lung attenuation with no obscuration of the underlying vessels and included reticular and/or interlobular thickened GGOs that are clearly distributed in the posterior and periphery of the lung (24). Among 21 patients with COVID19 in China, GGOs were observed in 12 patients (57\%), and consolidation was observed in six patients (29\%) (25). COVID19 is most likely to affect more than two lung lobes with bilateral involvement, with rapid evolution from focal, unilateral to diffuse, bilateral GGOs that progress to or coexist with consolidations within 1-3 weeks (26). CT is not specific for newborns, especially premature babies (27), and requires further scrutiny in case of diagnostic error. Although positive nucleic acid testing is the diagnostic gold standard, patients with fever and/or cough and prominent GGO lesions in the peripheral and posterior parts of the lungs on CT images, combined with normal or decreased white blood cells and a history of confirmed exposure, should be highly suspected of having COVID-19 (24). As a promising prognostic indicator for the clinical management of COVID-19, CT quantification of pneumonia lesions using artificial intelligence algorithms can predict the progression of serious diseases (28). A multicenter cohort study in 625 COVID19 patients demonstrated that the consolidation in the upper lungs on initial CT was a risk factor associated with an adverse clinical outcome (29). The changes in CT images can help evaluate the treatment response of patients with COVID-19 (30). CT may also assist in the early detection of coronavirus cases. Chest radiography may also be considered to be a useful diagnostic tool for monitoring the rapid progression of lung abnormalities in COVID-19, particularly in the intensive care unit (ICU) (31). The sensitivity and specificity of chest CT were 85 and $50 \%$, respectively, and sensitivity was significantly higher than that of X-ray (56\%) (32). Compared to CT, chest radiography is cheaper and more accessible, which can minimize the risk of cross-infection (33). However, chest radiographs may provide a limited diagnosis because they may be normal in early or mild disease (34). Overall, imaging must be combined with other laboratory tests to establish the cause of the pneumonia observed by the CT scan. However, it still has certain limitations in terms of early diagnosis and differential diagnosis or correct diagnosis, and it cannot replace pathogen detection.

\section{NEXT-GENERATION SEQUENCING OF SEVERE ACUTE RESPIRATORY SYNDROME CORONAVIRUS 2}

In the early stages of the pandemic, the first method used to detect the pathogen was next-generation sequencing (NGS) technology
(35). This technique produces genome-wide coverage in a single experiment and measures each nucleotide position repeatedly (4, 36). Analyses of MERS-CoV genetics have been performed using capture-based NGS approach or deep genome sequencing for complete genome analysis $(37,38)$. Considering the high genetic diversity of bat coronavirus (39), NGS can ensure unbiased sequencing and quickly determine the nucleic acid sequence of this novel coronavirus. De novo SARS-CoV-2 genome sequences of clinical specimens (bronchoalveolar lavage fluid) and human airway epithelial virus isolates were obtained by Illumina and Nanopore sequencing (35). The viral genome sequence was released for immediate public health support via the community online resource virological.org on January 10, 2020 (WuhanHu-1, GenBank accession number MN908947) (40), followed by four other genomes that were deposited on January 12 in the viral sequence database curated by the Global Initiative on Sharing All Influenza Data (GISAID) (41). However, unbiased NGS is an expensive method, and because of the high background level of non-viral sequences present in field monitoring samples, it is easy to miss low-abundance coronavirus sequences (38). With the emergence of the pandemic, a variety of COVID19 detection kits have been rapidly developed worldwide, and as a result of the discovery of specific nucleic acid detection technology, the diagnostic value of NGS has decreased because of its high cost (42). In addition, the limitations of NGS include the long sample-to-result turnaround time ( $>2$ days), limitations in the knowledge of how to interpret novel or rare mutations, and limited ability to detect structural gene variation and copy number variation (43).

\section{REAL-TIME REVERSE TRANSCRIPTASE-POLYMERASE CHAIN REACTION ANALYSIS}

rRT-PCR is more sensitive than conventional RT-PCR and has become the method of choice for the diagnosis of human coronaviruses (44). Sensitive rRT-PCR assays are essential for the rapid diagnosis of SARS-CoV in the early stages of the disease; multiple rRT-PCR assays have been developed to detect all four respiratory tract $\mathrm{HCoVs}$ that can be further adapted for the new CoV (45). SARS-CoV can be quickly detected by rRT-PCR analysis, which is based on multiple primers and probe sets located in different regions of the SARS-CoV genome and can distinguish SARS-CoV from other human and animal coronaviruses with a potential detection limit of $<10$ genomic copies per reaction. Clinical rRT-PCR testing has been shown to be suitable for the detection of SARS-CoV in clinical specimens and is valuable for the diagnosis of SARS$\mathrm{CoV}$ infection. However, the effectiveness of rRT-PCR for the detection of SARS-CoV in clinical specimens is greatly affected by the number, type, and timing of specimen collection (46). False-negative results may also be caused by mutations in the primer and probe target regions in the SARS-CoV genome. rRTPCR also remains the gold standard to confirm MERS-CoV. Upstream of the E gene (upE), ORF1a, ORF1b, and N genes are common targets for RT-PCR analysis of MERS-CoV (Table 1), while RNA-dependent RNA polymerase (RdRp), ORF1b, and 
$\mathrm{N}$ genes are targets for sequencing. The TaqMan probe-based one-step PCR assays allow for the rapid and sensitive internal diagnostic detection of MERS-CoV by detecting upE and ORF1b. In traditional RT-PCRs, step 1 is reverse transcription (RT) of RNA into cDNA, and step 2 is real-time PCR. The TaqMan probe-based one-step PCR kits use synthetic DNA templates and include the reverse transcriptase and DNA polymerase, which are premixed in a single reaction. The one-step method is reliable, specific, and reproducible (52). Compared to traditional RT-PCR, the one-step method combines two steps into one step, thus increasing the lower limits of sensitivity of the measurement; for example, $<10$ and $\leq 50$ copies of RNA template per reaction are required for upE and ORF1b in MERS-CoV, respectively (52). ORF1ab/N gene nucleic acid assays are currently used for the detection of SARS-CoV-2. The expected amplicon sizes of the ORF1b and N gene assays for SARS-CoV-2 are 132 and $110 \mathrm{bp}$, respectively (53).

rRT-PCR analysis of SARS-CoV-2 in the respiratory tract, urine, stool, and blood specimens has been developed by several companies internationally. Since the RNA is susceptible to hydrolysis, cold chain transportation must be used during sample delivery. Specimens that can be delivered promptly to the laboratory can be stored and shipped at $2-8^{\circ} \mathrm{C}(54)$. When there is likely to be a delay in specimens reaching the laboratory, specimens may be frozen to $-20^{\circ} \mathrm{C}$ or ideally $-80^{\circ} \mathrm{C}$ and shipped on dry ice if further delays are expected (54). After freezing and thawing more than four times, specimens will be damaged. A positive test for SARS-CoV-2 by rRT-PCR or gene sequencing revealing high homology to the SARS-CoV-2 gene can be used as a diagnostic criterion for suspected clinical cases (47). In clinical samples that have tested positive, the $\mathrm{N}$ gene assay is $\sim 10$ times more sensitive than the ORF1b gene assay in detecting positive clinical specimens (53). In the process of infection, subgenomic mRNA is necessary for virus replication. It contains multiple translation initiation sites and can encode structural proteins of the virus (55). It is possible that these clinical samples contain infected cells expressing subgenomic mRNA (56), resulting in more $\mathrm{N}$ gene copies in the samples. As these samples can only be qualitatively tested by these assays at the test site, the exact copy number in these samples cannot be determined (53). To confirm that a case is positive in the laboratory, the cycle threshold value in the rRT-PCR is the basis for judgment (a cycle threshold value $\leq 37$ cycles is confirmed as positive in most labs) (57). According to the SARS-CoV2 isolate Wuhan-Hu-1 (GenBank: MN908947.3), the conserved and specific regions are ORF1a (266-13468 nt), ORF1b (13469$21555 \mathrm{nt})$, and the $\mathrm{N}$ gene (28274-29533 nt) (58). The molecular detection primers and probes used for the rRT-PCR detection of SARS-CoV-2, SARS-CoV, and MERS-CoV are shown in Table 1. For SARS-CoV-2, nucleic acid extraction is performed by the one-step method or the use of magnetic beads. The one-step method requires no RNA extraction, and viral lysis, reverse transcription, amplification, and detection are achieved in a single-tube homogeneous reaction (59). The magnetic bead method utilizes nanotechnology to prepare superparamagnetic silicon oxide nanomagnetic beads, which can specifically identify and efficiently bind to nucleic acid molecules at the microscopic

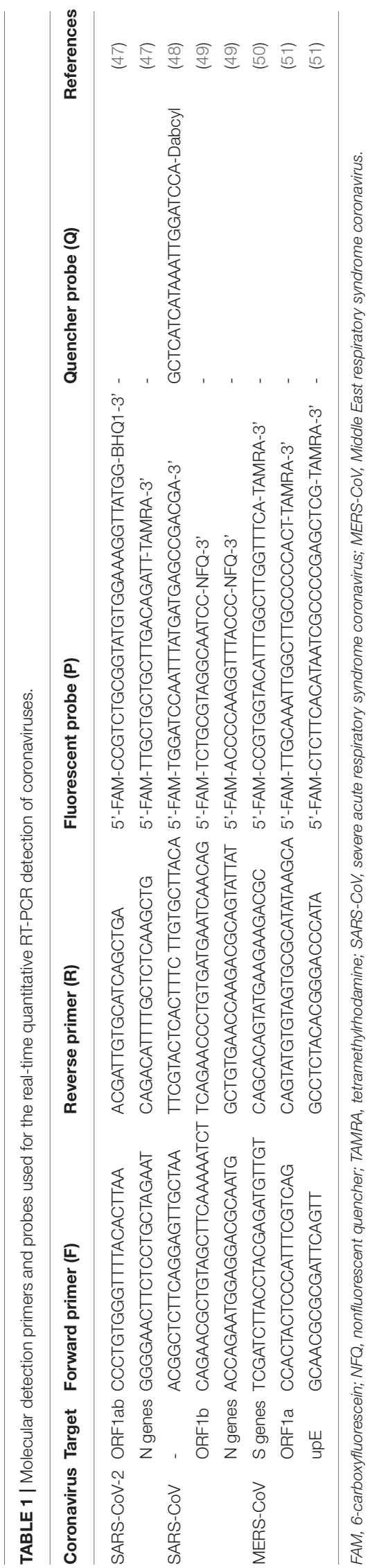


TABLE 2 | Detection of SARS-CoV-2 nucleic acid by molecular technology methods.

\begin{tabular}{|c|c|c|c|c|c|c|c|c|c|c|}
\hline Company & $\begin{array}{l}\text { Assay } \\
\text { (nucleic acid } \\
\text { extraction) }\end{array}$ & $\begin{array}{l}\text { Amplification } \\
\text { method }\end{array}$ & Specimen source & Target & $\begin{array}{l}\text { Detection } \\
\text { time (min) }\end{array}$ & $\begin{array}{c}\text { PPA } \\
\text { (\%) (no.) }\end{array}$ & $\begin{array}{c}\text { NPA } \\
\text { (\%) (no.) }\end{array}$ & $\begin{array}{l}\text { DR } \\
(\%)\end{array}$ & Eligibility & References \\
\hline Applied Bio-Tech & Magnetic beads & Standard PCR & Respiratory tract & ORF1ab/N/E & 90 & $100.0(-)$ & $100.0(-)$ & 100.0 & NMPAWHO & (57) \\
\hline $\begin{array}{l}\text { Bioperfectus } \\
\text { Technologies }\end{array}$ & Magnetic beads & Standard PCR & Respiratory tract/Stool & ORF1ab/N/E & 90 & $97.2(970)$ & $100.0(970)$ & 100.0 & $\begin{array}{l}\text { NMPAWHO/US } \\
\text { FDA EUA } \\
\text { /TGA }\end{array}$ & $(57,61)$ \\
\hline DAAN Gene & Magnetic beads & Standard PCR & $\begin{array}{l}\text { Respiratory } \\
\text { tract/Serum/Urine/Stool }\end{array}$ & ORF1ab/N & 110 & $100.0(-)$ & $100.0(-)$ & 83.3 & NMPA/WHO/TGA & $(57,61)$ \\
\hline Zybio & Magnetic beads & Standard PCR & $\begin{array}{l}\text { Respiratory } \\
\text { tract/Serum/Urine/Stool }\end{array}$ & ORF1ab/N & 60 & $100.0(-)$ & $100.0(-)$ & 100.0 & NMPA & (57) \\
\hline BGI Genomics & Magnetic beads & Standard PCR & $\begin{array}{l}\text { Respiratory } \\
\text { tract/Serum/Urine/Stool }\end{array}$ & ORF1ab & - & $88.1(126)$ & 99.6 (258) & 97.0 & $\begin{array}{l}\text { NMPA/US FDA } \\
\text { EUA }\end{array}$ & (54) \\
\hline Maccura Biotechnology & Magnetic beads & Standard PCR & $\begin{array}{l}\text { Oropharyngeal } \\
\text { swabs/nasopharyngeal } \\
\text { swabs/nasal swabs }\end{array}$ & ORF1ab/N/E & - & $100.0(20)$ & $96.7(30)$ & - & US FDA EUA & (54) \\
\hline Thermo Fisher & Magnetic beads & Standard PCR & $\begin{array}{l}\text { Respiratory } \\
\text { tract/Serum/Urine/Stool }\end{array}$ & ORF1ab/N/S & 60 & $100.0(-)$ & $100.0(-)$ & 100.0 & US FDA EUA & (54) \\
\hline ZJ Bio-Tech & Magnetic beads & Standard PCR & Respiratory tract/Stool & ORF1ab/N/E & 120 & $100.0(252)$ & $100.0(252)$ & 100.0 & NMPA/WHO & (62) \\
\hline Coyote Bioscience & One-step & Standard PCR & Respiratory tract & ORF1ab/N & 30 & - & - & 66.6 & NMPATTGA & (57) \\
\hline $\begin{array}{l}\text { Easydiagnosis } \\
\text { Biomedicine }\end{array}$ & One-step & Standard PCR & Respiratory tract & ORF1ab/N & 75 & $95.9(750)$ & $94.1(750)$ & 94.8 & NMPA/TGA & (63) \\
\hline Orient Gene Biotech & One-step & Standard PCR & Respiratory tract & ORF1ab/N & 30 & - & - & 97.0 & NMPA & (64) \\
\hline Promega & One-step & & Respiratory tract & $\mathrm{N}$ & - & $100.0(13)$ & $100.0(104)$ & 100.0 & - & $(65)$ \\
\hline SANSURE Bio-Tech & $\begin{array}{l}\text { One- } \\
\text { step/Magnetic } \\
\text { beads }\end{array}$ & Standard PCR & $\begin{array}{l}\text { Respiratory } \\
\text { tract/Serum/Urine/Stool }\end{array}$ & ORF1ab/N & 30 & $100.0(-)$ & $100.0(-)$ & 100.0 & $\begin{array}{l}\text { NMPA/US FDA } \\
\text { EUA/TGA }\end{array}$ & $(57,66)$ \\
\hline Mammoth Biosciences & $\begin{array}{l}\text { CRISPR-based } \\
\text { DETECTR }\end{array}$ & & $\begin{array}{l}\text { Oropharyngeal } \\
\text { swabs/Nasopharyngeal } \\
\text { swabs }\end{array}$ & $N / E$ & 40 & $95.0(30)$ & $100.0(30)$ & - & US FDA EUA & (67) \\
\hline - & $\begin{array}{l}\text { Cas13-based } \\
\text { SHERLOCK }\end{array}$ & Isothermal & $\begin{array}{l}\text { Nasopharyngeal and throat } \\
\text { swab }\end{array}$ & ORF1ab/N/S & - & $100.0(154)$ & $87.95(154)$ & - & - & (68) \\
\hline Biofire & - & Standard PCR & Nasopharyngeal Swab & ORF1ab/ORF8 & - & $100.0(33)$ & $100.0(66)$ & 100.0 & US FDA EUA & (54) \\
\hline $\begin{array}{l}\text { Rutgers Clinical } \\
\text { Genomics Laboratory }\end{array}$ & - & Standard PCR & Saliva & ORF1ab/N/S & - & $100.0(30)$ & $100.0(30)$ & - & - & (54) \\
\hline Abbott ID Now & - & Isothermal & $\begin{array}{l}\text { Nasal, nasopharyngeal and } \\
\text { throat swabs }\end{array}$ & RdRp & 13 & $94.0(96)$ & $100.0(30)$ & - & $\begin{array}{l}\text { US FDA } \\
\text { EUATTGA }\end{array}$ & (54) \\
\hline Cepheid & - & Standard PCR & Nasopharyngeal Swab & $\mathrm{N}_{2} / \mathrm{E}$ & 30 & $97.9(240)$ & $100.0(240)$ & - & $\begin{array}{l}\text { WHO/US FDA } \\
\text { EUATGA }\end{array}$ & (54) \\
\hline Diasorin Molecular & - & Standard PCR & $\begin{array}{l}\text { Nasopharyngeal } \\
\text { swabs/nasal } \\
\text { swabs/bronchoalveolar } \\
\text { lavage }\end{array}$ & ORF1ab/S & - & $100.0(-)$ & $100.0(-)$ & 100.0 & $\begin{array}{l}\text { WHO/US FDA } \\
\text { EUA/TGA }\end{array}$ & (54) \\
\hline
\end{tabular}


interface for RNA extraction (60). In Table 2, information is collected on several biotechnology companies undertaking the molecular diagnosis of COVID-19, including specimen source, methods of nucleic acid extraction, gene targeting, detection time, negative/positive percent agreement (NPA/PPA), and detection rate (DR). The analysis can be performed in as fast as $30 \mathrm{~min}$ with kits from Zhejiang Orient Gene Biotech Co., Ltd., Coyote Bioscience Co., Ltd. (57), and Hunan SANSURE BIOTECH INC. $(57,66)$. There are four companies (Cepheid, Diasorin Molecular, PerkinElmer, and Roche Diagnostics) on the list of SARS-CoV-2 diagnostic test kits by rRT-PCR analysis, which are updated on the Global Fund (GF) resources website based on eligibility criteria of WHO and US Food and Drug Administration (FDA) and Emergency Use Authorization (EUA) (69) and are shown in Table 2.

Compared with conventional RT-PCR, the loop-mediated isothermal amplification (LAMP) is 100 -fold-greater sensitivity for detection of SARS-CoV, with a detection limit of $0.01 \mathrm{PFU}$ (70). By doing the LAMP assay, the virus is quickly extracted and amplified at constant temperature without the expensive reagents and equipment (71), but LAMP may be of lower sensitivity or comparable to SARS-CoV-2 detection by RT-PCR. Rödel et al. (72) demonstrated that the isolated RNA variplex RT-LAMP for SARS-CoV-2 had a sensitivity of $75 \%$ compared to LightMix E gene RT-PCR. On the other hand, the ID NOW COVID-19 assay performed on the ID NOW Instrument is a rapid $(5-13 \mathrm{~min})$ in vitro molecular diagnostic test, which utilizes isothermal nucleic acid amplification technology and amplification of the unique region of RdRP segment and nicking and extension amplification reaction (NEAC) where each primer consists of binding region and nicking enzyme recognition site. The newly synthesized short-sequence single-stranded chain is combined with the fluorescently labeled molecular probes to provide a realtime readout (54). The sensitivity and NPA of ID NOW can reach 87.58 and $96.99 \%$, respectively. The saliva test has also demonstrated a high sensitivity and comparable performance to the current standard of nasopharyngeal and throat swabs and can significantly minimize the likelihood of exposing health care workers to SARS-CoV-2 while sampling $(54,73)$.

In addition to RT-PCR and isothermal amplification, clustered regularly interspaced short palindromic repeats (CRISPR)-based technologies have also been developed to detect the nucleic acids of SARS-CoV-2 in <40 min (67). This assay performs simultaneous reverse transcription and isothermal amplification, followed by Cas 12 detection of SARS-CoV-2 sequences, after which cleavage of a reporter molecule confirms the detection of the virus. The kit provides a visual and faster method of detection, which showed 95\% PPA and 100\% NPA (67). It is a portable assay that enables point of care (POC) outside of the clinical diagnostic laboratory and replaces regular RT-PCR. Additionally, the specific high-sensitivity enzymatic reporter unlocking (SHERLOCK) assay using the enzyme Cas13a was developed for the detection of SARS-CoV-2, and the PPA of this assay is as high as $100 \%(68)$.

Specifically, some novel mutations of SARS-CoV-2 have already been identified as B.1.1.7, B.1.351, P.1, N501Y, and HV69$70 \mathrm{del}(74,75)$. A one-step reverse transcription and real-time 
PCR (RT-qPCR) test is developed for screening Spike N501Y and HV69-70del mutations in $40 \mathrm{~min}$. The specificity of this RTqPCR assay relative to the sequencing-based technologies is $100 \%$ and can screen for SARS-CoV-2 efficiently (75).

\section{IMMUNOASSAY FOR CORONAVIRUS DISEASE 2019}

False-negative results are often obtained in the rRT-PCR analyses of coronavirus because nucleic acid assays can be affected by low virus copies or efficiency during amplification. For the detection of SARS-CoV antigens, a chemiluminescence enzymelinked immunosorbent assay (CLEIA) can sensitively detect the target protein below $2 \mathrm{pg} / \mathrm{ml}$ at different stages of infection. The CLEIA shows no cross-reactivities to recombinant nucleocapsid (N) proteins of coronaviruses such as 229E, OC43, and NL63, and the specificity and sensitivity of this assay are both $100 \%$ (76). In addition, double-antibody sandwich enzyme-linked immunosorbent assays (ELISAs) based on specific monoclonal antibodies are used to detect the N proteins of HCoV-NL63 and HCoV-229E (77) and the SARS-CoV S protein of SARS-CoV (78). For the detection of MERS-CoV, an ELISA capture assay is developed to detect the $\mathrm{N}$ protein antigen of MERS-CoV virus in nasopharyngeal samples with high specificity (almost 100\%) and sensitivity $(<1 \mathrm{ng} / \mathrm{ml})(79)$. Under an EUA, the Sofia 2 SARS Antigen Fluorescent Immunoassay (FIA) can be the practice of qualitative detection of $\mathrm{N}$ protein from SARS-CoV-2 in $15 \mathrm{~min}$ by immunofluorescence-based lateral flow technology for testing of patients suspected of COVID-19 (54).

Compared with rRT-PCR assays of upper respiratory tract samples, immunoassays are used to detect antibodies against SARS-CoV-2 from blood samples of patients suspected to have the active disease or to have had the disease in the past and thus are not used to detect the virus directly. The time window is also important for virus-specific antibody detection (80). Serology is the practice of detecting antibodies and can increase the sensitivity and specificity of SARS-CoV detection and is suitable for rapid laboratory diagnosis. SARS-CoV-2 proteins are used as the coated antigens to identify virus-specific $\operatorname{IgM} / \operatorname{IgG}$ antibodies in blood samples of patients with COVID-19. The study showed that (81) IgM and IgG antibodies against SARSCoV-2 were detected as early as the fourth day after the onset of symptoms and that IgG increased sharply by the 12th day. At 28 days, the seropositivity of $\operatorname{IgG}$ decreased, which were detected by ELISA kits from Livzon Diagnostics Inc. The sensitivity, specificity, and positive predictive value (PPV) of IgM antibodies were $77.3 \%(51 / 66), 100 \%$, and $100 \%$, respectively (81). The specificity and PPV of IgG-IgM combined detection assays are higher than those of individual IgG or IgM antibody assays (82). We also classify and describe the specimen sources, detection methods, detected antibodies, virus targets, detection times, and specificities and sensitivities of SARS-CoV-2 antibody detection kits according to the manufacturers' protocols (Table 3). The detection time of the colloidal gold method is short (15 min), and the virus targets are mainly $\mathrm{S}$ or $\mathrm{N}$ protein. The assay methods from Cellex using colloidal gold showed sensitivity and specificity to be more than $90 \%$. The kit from Mount Sinai Laboratory also showed outstanding high sensitivity $(92 \%)$ and specificity (100\%). There are five companies (Advaite, Biocan Diagnostics, Biohit Healthcare, Biotest Biotech, and Laihe Biotech) on the list of diagnostic test kits using colloidal gold, which are updated on the GF resources website based on eligibility criteria of US FDA and EUA (69) and shown in Table 3. The ELISA from Beijing WANTAI BioPharm Co., Ltd., can simultaneously detect total antibodies $(\operatorname{IgG} / \operatorname{IgM} / \operatorname{IgA})$. Moreover, the sensitivity and specificity of WANTAI BioPharm Co., Ltd., reach $\sim 100 \%$ (83). The Chembio Dual Path Platform (DPP) COVID-19 $\mathrm{IgM} / \mathrm{IgG}$ System is a single-use rapid immunochromatographic test for the qualitative detection of antibodies to SARS-CoV2. The device employed Chembio's patented DPP technology that uses antibody capture to detect SARS-CoV-2 (54). If the sample contains SARS-CoV-2 antibodies, the conjugate binds to the antibodies captured in the test areas with more than $90 \%$ sensitivity and specificity. Rapid tests have great potential benefits for the prompt screening of COVID-19 infections. Thus, serological diagnostic approaches will aid in the diagnosis and treatment of novel coronavirus pneumonia and will also test the effectiveness of the vaccines and the selection of individuals who might act as plasma donors. However, rRT-PCR is widely adopted as the standard diagnostic method for SARS-CoV-2. Specifically, combining IgM and IgG detection methods with rRT-PCR assay results for the detection of the virus will greatly increase the accuracy of establishing the time of infection and predicting the progress of the disease (Table 4). Although the relationship between IgG levels in COVID-19 patients and protective immunity to SARS-CoV-2 virus has not been fully established (84), a positive result indicates an immune response to SARS-CoV-2 in COVID-19 patients. However, the patient is infected but has not yet produced $\operatorname{IgG} / \operatorname{IgM}$ antibodies at detectable levels, resulting in false negatives (85). Also, crossreactivity occurs when antibodies bind with an antigen, which is similar to the SARS-CoV-2 antigen, leading to a falsepositive result. Thus, cross-reactivity is the biggest issue in the serological test.

\section{EFFECT OF CYTOKINES AND T CELLS ON CORONAVIRUS DISEASE 2019}

SARS-CoV-2 can act as a factor for the development of a rapid autoimmune response that underlines COVID-19 outcomes. It is an important cause of acute respiratory distress syndrome and multiorgan illness that lasted for months in people with "long COVID" $(86,87)$. More than $10 \%$ of 987 patients with severe COVID-19 had antibodies that attacked and blocked the action of type 1 interferon, which could help to bolster the immune response against the virus (88) and played a key role in the pathophysiology of COVID-19 (89). After a novel coronavirus infection, pathogenic $\mathrm{T}$ cells are rapidly activated, and a large number of plasma cytokines and chemokines are produced, which causes a cytokine storm leading to severe immune damage to multiple organs $(12,90)$. Autoantibodies are more 
TABLE 3 | Immunoassays for COVID-19.

\begin{tabular}{|c|c|c|c|c|c|c|c|c|c|}
\hline Company & $\begin{array}{l}\text { Assay } \\
\text { (detection } \\
\text { method) }\end{array}$ & $\begin{array}{l}\text { Specimen } \\
\text { source }\end{array}$ & $\begin{array}{l}\text { SARS CoV-2 } \\
\text { targets }\end{array}$ & $\begin{array}{l}\text { Antibody } \\
\text { detected }\end{array}$ & Time (min) & $\begin{array}{l}\text { Sensitivity } \\
\text { (\%) (no.) }\end{array}$ & $\begin{array}{l}\text { Specificity } \\
\text { (\%) (no.) }\end{array}$ & Eligibility & References \\
\hline Wandfo & Colloidal gold & $\begin{array}{l}\text { Peripheral blood/ } \\
\text { Serum/Plasma }\end{array}$ & s & $\lg G / \lg M$ & 15 & $86.4(596)$ & $99.6(596)$ & NMPA & a \\
\hline Innovita & Colloidal gold & $\begin{array}{l}\text { Peripheral } \\
\text { blood/Serum/Plasma }\end{array}$ & $\mathrm{N}$ & $\lg G / \lg M$ & 15 & $87.3(126)$ & $100.0(126)$ & $\begin{array}{l}\text { NMPA/US FDA } \\
\text { EUA/TGA }\end{array}$ & b \\
\hline Autobio Diagnostics & Colloidal gold & Serum/Plasma & $\mathrm{s}$ & $\lg G / \lg M$ & 15 & $88.2(405)$ & $99.0(312)$ & NMPA & c \\
\hline Cellex & Colloidal gold & $\begin{array}{l}\text { Peripheral } \\
\text { blood/Serum/Plasma }\end{array}$ & - & $\lg G / \lg M$ & 15 & $93.8(128)$ & $96.0(250)$ & $\begin{array}{l}\text { US FDA } \\
\text { EUA/TGA }\end{array}$ & c \\
\hline Mount Sinai Laboratory & ELISA & Serum/Plasma & $\mathrm{s}$ & $\lg G$ & - & $92.0(40)$ & $100.0(74)$ & - & c \\
\hline Ortho Clinical Diagnostics & ELISA & Serum/Plasma & $S$ & $\lg G / \lg M$ & 48 & $83.3(36)$ & $100.0(400)$ & US FDA EUA & c \\
\hline WANTAI BioPharm & ELISA & Serum/Plasma & $\mathrm{s}$ & $\operatorname{lgG} / \operatorname{lgM} / \lg A$ & 120 & $100.0(28)$ & $98.0(84)$ & $\begin{array}{l}\text { NMPA/US FDA } \\
\text { EUA/TGA }\end{array}$ & d \\
\hline Chembio Diagnostic System & DPP & $\begin{array}{l}\text { Peripheral } \\
\text { blood/Serum/Plasma }\end{array}$ & $\mathrm{N}$ & $\lg G / \operatorname{lgM}$ & 15 & $93.5(31)$ & $90.2(41)$ & - & c \\
\hline Quidel & ELISA & $\begin{array}{l}\text { Nasopharyngeal } \\
\text { and nasal swab }\end{array}$ & $\mathrm{N}$ & - & 15 & $80.0(48)$ & $100.0(48)$ & $\begin{array}{l}\text { US FDA } \\
\text { EUA/TGA }\end{array}$ & c \\
\hline Advaite & Colloidal gold & Peripheral blood & - & $\lg G$ & 20 & $90.0(30)$ & $95.2(104)$ & US FDA EUA & c \\
\hline Biocan Diagnostics & Colloidal gold & Serum/Plasma & $\mathrm{N} / \mathrm{S}$ & $\lg G / \lg M$ & - & 93.3(-) & $96.2(-)$ & US FDA EUA & c \\
\hline Biohit Healthcare & Colloidal gold & Serum/Plasma & $\mathrm{N}$ & $\lg G / \lg M$ & 20 & $96.7(30)$ & $95.0(80)$ & US FDA EUA & c \\
\hline Biotest Biotech & Colloidal gold & Serum/Plasma & $\mathrm{s}$ & $\lg G / \lg M$ & 20 & $100.0(30)$ & $100.0(30)$ & US FDA EUA & c \\
\hline Laihe Biotech & Colloidal gold & Serum/Plasma & $\mathrm{s}$ & $\lg G / \lg M$ & 30 & $100.0(30)$ & $98.8(80)$ & US FDA EUA & c \\
\hline
\end{tabular}

NO. is the number of samples tested; NMPA, National Medical Products Administration of China; US FDA EUA, Food and Drug Administration (FDA) and Emergency Use Authorization (EUA) of the United State; TGA, Therapeutic Goods Administration; DDP, dual path platform; COVID-19, coronavirus disease 2019; SARS-CoV, severe acute respiratory syndrome coronavirus. (a) Guangzhou Wandfo Co., Ltd. (http://tech.gmw.cn/2020-02/24/content 33583856. htm); (b) INNOVITA Co., Ltd. (http://www.innovita.com.cn/htm//cn/); (c) US Food \& Drug administration (https://www.fda.gov/medical-devices/emergency-situations-medical-devices/emergency-use-authorizations); (d) Shenzhen Third

People's Hospital in conjunction with Xiamen University and Beijing WANTAl BioPharm Co., Ltd. (https://www.medrxiv.org/content/10.1101/2020.04.09.20056325v1). 
TABLE 4 | Clinical significance of SARS-CoV-2 detection in COVID-19 patients.

\begin{tabular}{|c|c|c|c|c|c|}
\hline \multirow{2}{*}{$\begin{array}{l}\text { SARS-CoV-2 } \\
\text { nucleic acid assay }\end{array}$} & \multicolumn{2}{|c|}{ Immunoassay } & \multicolumn{3}{|c|}{ Clinical significance } \\
\hline & $\lg M$ & $\lg G$ & Infection period* & $\begin{array}{c}\text { Immune response } \\
\text { (Yes/No) }\end{array}$ & Other remarks \\
\hline+ & + & + & Middle/Late & Yes & / \\
\hline+ & + & - & Early & Yes & / \\
\hline+ & - & + & Middle/Late & Yes & / \\
\hline+ & - & - & / & No & "Window period" for 2 weeks \\
\hline- & + & + & / & Yes & Recovery/false-negative nucleic acid test \\
\hline- & + & - & Early & Yes & $\begin{array}{l}\text { http://www.baidu.com/link?url=OkXBuXMzX8-U029eB-yK4e } \\
\text { mFTye783LAu2tVaOpN8Am0q9DpIOpEzaFkTwUwFGcoK2ryb } \\
\text { VT1QQbEduUJEy4ar-mKBgjVCPwhOQ91QYDljmReview } \\
\text { for nucleic acid test }\end{array}$ \\
\hline- & $+/-$ & - & Early & No & Review after 1 week \\
\hline- & - & + & / & Yes & Past exposure to SARS-CoV-2 \\
\hline- & - & - & / & / & Health/latent period (0-14 days) \\
\hline
\end{tabular}

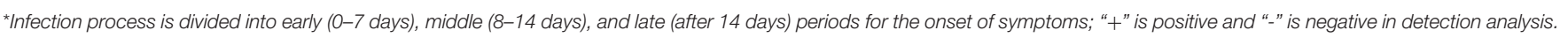
COVID-19, coronavirus disease 2019; SARS-CoV, severe acute respiratory syndrome coronavirus.

common in men than in women, and a poor $\mathrm{T}$ cell response negatively correlated with patients' age and was associated with worse disease outcome in male patients, which provides a possible explanation as to why COVID hits men harder (91). Cytokine storm refers to a phenomenon in which a large number of cytokines are rapidly released into bodily fluids after the patient is infected with microorganisms. Among T lymphocyte subpopulations in patients with COVID-19, both $\mathrm{CD}^{+}$and $\mathrm{CD}^{+}{ }^{+} \mathrm{T}$ cell counts decreased, and the reduction in $\mathrm{CD} 4^{+} \mathrm{T}$ cells was more pronounced (42). However, in children, leukocyte counts and absolute lymphocyte counts were mostly normal (92). It was reported that interleukin (IL)-6 was elevated in more than half (52\%) of patients with COVID-19 (90). In the early stage, initial plasma IL-1B, IL-1RA, IL-7, IL-8, IL-9, IL-10, basic fibroblast growth factor (FGF), granulocyte colony-stimulating factor (GCSF), granulocyte/macrophage colony-stimulating factor (GMCSF), interferon (IFN) $\gamma$, IFN $\gamma$-inducible protein (IP)10, monocyte chemotactic protein (MCP)1, macrophage inflammatory protein 1-alpha (MIP1A), MIP1B, platelet-derived growth factor (PDGF), tumor necrosis factor (TNF) $\alpha$, and vascular endothelial growth factor (VEGF) concentrations were higher in all patients than those in healthy adults (12). The binding of COVID-19 to the Toll-like receptor (TLR) led to the release of pre-IL-1 $\beta$, which was cleaved by caspase-1, followed by the activation of the inflammasome and the production of active mature IL-1 $\beta$, which is a mediator of lung inflammation (62). Compared to those in non-ICU patients, IL-2, IL-7, IL-10, GCSF, IP10, MCP1, MIP1A, and TNF $\alpha$ levels were higher in ICU patients, suggesting that the cytokine storm was associated with disease severity (12). It was also found that the inflammatory factors IL-2R, IL-6, and C-reactive protein (CRP) were elevated in COVID-19 patients, and IL-2R and IL-6 had certain advantages in predicting the severity of the disease compared with traditional indicators (lymphocyte count and CRP) (93).

\section{BLOOD, BIOCHEMISTRY, AND MICROBIOLOGY LABORATORY PARAMETERS OF CORONAVIRUS DISEASE 2019}

In the early stage of COVID-19, the total number of white blood cells was generally reduced or normal, the lymphocyte count was decreased, and monocyte counts were increased or normal. If the absolute value of lymphocytes was $<0.8 \times 10^{9} / \mathrm{L}$, the general recommendation was to review routine blood changes after 3 days. Leukopenia was observed in approximately $33.7 \%$ of the overall COVID-19 patient population. Among these patients, $82.1 \%$ had lymphopenia and $36.2 \%$ had thrombocytopenia. Moreover, lymphocytopenia, leukopenia, and thrombocytopenia were significant in severe cases of COVID-19 (94). The examination of peripheral blood cell morphology could show abnormal lymphocytes, and Dohle bodies could be found in the cytoplasm of some neutrophils (92).

In 99 cases of COVID-19 in Wuhan, most patients had common inflammation-like biochemical indicators on admission. Seventy-three patients were tested for CRP, of whom $63(86 \%)$ patients had increased levels of CRP. Forty-three of 99 patients had differing degrees of liver damage, as shown by abnormal levels of alanine aminotransferase (ALT) or aspartate aminotransferase (AST). A large number of patients, 98\%, had decreased serum albumin levels. In addition, there was an increase in serum ferritin (FER) in $62(63 \%)$ patients, an increase in erythrocyte sedimentation rate (ESR) in $84(85 \%)$ patients, and an increase in the levels of blood glucose in 51 (52\%) patients (90). In another report on COVID-19 (12), levels of lactate dehydrogenase (LDH) were elevated above $245 \mathrm{U} / \mathrm{L}$ in 29 of 40 (73\%) patients, including 12 of 13 (92\%) patients requiring ICU care and 17 of 27 (63\%) of non-ICU patients. Of the 40 patients, five $(12 \%)$ patients had levels of hypersensitive troponin I (hscTnI) above $28 \mathrm{pg} / \mathrm{ml}$, which was due to virus-related cardiac 
injury, including 4 of 13 (31\%) patients in the ICU. Procalcitonin (PCT) is a protein used to determine whether there is a bacterial infection in the lungs (95). On admission, the levels of PCT were in the normal range (PCT $<0.1 \mathrm{ng} / \mathrm{ml}$ ) for $27(69 \%)$ of 39 patients. PCT levels were increased above $0.5 \mathrm{ng} / \mathrm{ml}$ in only three $(8 \%)$ of the 39 patients. Among the 39 patients, there were four ICU patients who developed secondary infections. Three of the four patients with secondary infections had PCT levels $>0.5 \mathrm{ng} / \mathrm{ml}$. The arterial oxygen saturation $\left(\mathrm{SpO}_{2}\right)$ and oxygen partial pressure decreased and carbon dioxide partial pressure increased in some severe cases of COVID-19, and those with metabolic acidosis occasionally had decreased $\mathrm{pH}$ (92).

COVID-19 is very different from other known viral pneumonia, such as influenza virus, adenovirus, respiratory syncytial virus, and mycoplasma pneumonia infections. Routinely detected influenza antigens are the $\mathrm{A}, \mathrm{B}$, and $\mathrm{H} 7 \mathrm{~N}$ subtypes (42). Due to the rapid detection method, the sampling of throat swabs can help to screen for influenza early in the clinical course, but the false-negative rate of the method is high (42). Therefore, the diagnosis of COVID-19 should be combined with nucleic acid, antibody, and antigen detection technology to improve the DR.

\section{RAPID DETECTION OF CORONAVIRUS DISEASE 2019 SEVERE ACUTE RESPIRATORY SYNDROME CORONAVIRUS 2 USING A FIELD-EFFECT TRANSISTOR-BASED BIOSENSOR}

A field-effect transistor (FET)-based biosensing device has been invented recently for detecting SARS-CoV-2 in clinical samples. FET-based biosensors are considered to be potentially useful in clinical diagnosis, POC testing, and on-site detection (96). The sensor is fabricated by coating graphene sheets of the FET with a specific antibody against SARS-CoV-2 spike protein. The sensor is able to detect the SARS-CoV-2 spike protein at concentrations of $1 \mathrm{fg} / \mathrm{ml}$ in phosphate-buffered saline and 100 $\mathrm{fg} / \mathrm{ml}$ clinical transport medium, which makes it a highly sensitive immunoassay for COVID-19. Additionally, the biosensor can avoid cross-reaction with MERS-CoV antigen, indicating that the FET sensor is sensitive and specific enough for the SARS-CoV-2 spike protein. This method does not require sample pretreatment and labeling, and the biosensor does not cross-react with SARS$\mathrm{CoV}$ and MERS-CoV antigens due to high specificity to SARSCoV-2 spike protein by the selected antibody (96).

\section{SUMMARY AND PROSPECTS FOR THE DETECTION OF SEVERE ACUTE RESPIRATORY SYNDROME CORONAVIRUS 2 IN CORONAVIRUS DISEASE 2019}

Coronavirus-related diseases have become an urgent global public health problem, and the detection of coronavirus is particularly important in the diagnosis of coronavirus diseases.
RT-PCR has been widely used in diagnostic virology, and skilled diagnostic laboratories can rely on this powerful technique to internally establish new diagnostic assays during public health emergencies. In the face of a sudden outbreak, rapid and accurate detection and triage, with the isolation or treatment of suspected and confirmed cases, are the most powerful measures to prevent further spread of disease. Therefore, the SARS-CoV-2 nucleic acid assay is an important medical test for prevention, control, and medical treatment during an epidemic.

For suspected cases of COVID-19, rapid antigen and multiple PCR nucleic acid detection methods should be adopted as widely as possible. The detection of nucleic acids is the leading advance in the current clinical diagnostic technology for pathogenic microorganisms and is guiding the direction of lung infection diagnostic technology. Most commonly, the DR of this method is over $90 \%$, and NPA and PPA are close to $100 \%$, and this method is widely used in the clinical diagnosis and detection of various respiratory pathogens. However, with the widespread use of SARS-CoV-2 nucleic acid assays, an increasing number of problems are becoming apparent. The major issue is a high number of false-negative results in virus nucleic acid detection.

For rRT-PCR analysis, the results of the nucleic acid assay are affected by factors such as the disease development process, specimen collection, specimen preservation and transportation, nucleic acid extraction, amplification system, detection operating environment, and personnel operations. The concentration of SARS-CoV-2 in the alveolar lavage fluid of COVID-19 patients is the highest, but the procedure of collecting alveolar lavage fluid is complicated, it is only recommended for critically ill patients on ventilators. However, the most common and simplest sampling method remains a throat swab. Moreover, the correct handling of specimens during transportation is essential. Specimens for virus detection should be kept cold and stored at $-70^{\circ} \mathrm{C}$ if the testing is to be delayed for a long time. Most of the (RNA) vaccines also require logistics for storage at very low temperatures. Previously, it was stated by Shanghai ZJ Bio-Tech Co., Ltd., that because their kit requires a storage environment of $-20^{\circ} \mathrm{C}$, only a few logistics companies with cold chain capabilities could supply the kit. Carelessness during transportation may affect the final test results of the assays. On the other hand, many sampling solutions cannot lyse the virus and cannot guarantee the stability of the viral nucleic acid, which is one of the factors that affects detection sensitivity.

Testing SARS-CoV-2-specific antibodies in patient blood is a good choice for rapid, simple, and highly sensitive diagnosis of COVID-19, which can also meet the urgent needs of a large number of patients. Hence, immunoassays are an excellent supplementary approach in clinical applications. Moreover, monoclonal antibodies have been developed against SARS-CoV2 antigen proteins, which can target a single specific epitope and are highly specific compared to polyclonal antibodies. Overall, compared with polyclonal antibodies, monoclonal antibodies have been indicated to be efficient reagents in terms of specificity for clinical diagnostic tests, which is greatly valuable for clinical detection. Some of the antibodies do not react with the new emerging mutant variants of the virus. Therefore, the diagnosis of COVID-19 needs to be further improved to reduce the 
misdiagnosis rate and to adapt to new mutated versions of SARS-CoV-2. Therefore, the diagnosis of COVID-19 needs to be further improved to reduce the misdiagnosis rate. Multiple detection methods can be used together to improve the correct diagnosis rate.

With the increase in the prevalence of SARS-CoV-2 variants containing spike mutations, a one-step rRT-qPCR test needs be developed that will rapidly detect mutations with low cost. When the evolution of the pandemic causes the number of asymptomatic SARS-CoV-2-positive individuals and patients with COVID-19 to grow exponentially, fully automated immunoassays and PCRs, capable of executing thousands of tests per day, have gained importance. New technologies, such as the POC diagnosis device, provide a portable, fast, and low-cost assay system for the diagnosis of COVID-19 that can be used not only in the doctor's offices but also in homes, airports, and remote locations. The integration of smartphones with COVID-19 detection technologies should be considered a promising testing platform in the future. Additionally, the development of a novel assay for coronavirus pneumonia still has a long way to

\section{REFERENCES}

1. Wevers BA, van der Hoek L. Recently discovered human coronaviruses. Clin Lab Med. (2009) 29:715-24. doi: 10.1016/j.cll.2009.07.007

2. Tyrrell DAJ, Bynoe ML. Cultivation of a novel type of common-cold virus in organ cultures. Br Med J. (1965) 1:1467-70. doi: 10.1136/bmj.1.5448.1467

3. Weiss SR, Navasmartin S. Coronavirus pathogenesis and the emerging pathogen severe acute respiratory syndrome coronavirus. Microbiol Mol Biol Rev. (2005) 69:635. doi: 10.1128/MMBR.69.4.635-664. 2005

4. van Boheemen S, de Graaf M, Lauber C, Bestebroer TM, Raj VS, Zaki AM, et al. Genomic characterization of a newly discovered coronavirus associated with acute respiratory distress syndrome in humans. mBio. (2012) 3:e0047312. doi: 10.1128/mBio.00473-12

5. Kin N, Miszczak F, Lin W, Gouilh M, Vabret A, Consortium E. Genomic analysis of 15 human coronaviruses OC43 (HCoV-OC43s) circulating in France from 2001 to 2013 reveals a high intra-specific diversity with new recombinant genotypes. Viruses. (2015) 7:2358-77. doi: 10.3390/v7052358

6. Zaki AM, van Boheemen S, Bestebroer TM, Osterhaus ADME, Fouchier RAM. Isolation of a novel coronavirus from a man with pneumonia in Saudi Arabia. N Engl J Med. (2012) 367:1814-20. doi: 10.1056/NEJMoa1211721

7. Zhong NS, Zheng BJ, Li YM, Poon, Xie ZH, Chan KH, et al. Epidemiology and cause of severe acute respiratory syndrome (SARS) in Guangdong, People's Republic of China, in February, 2003. Lancet. (2003) 362:13538. doi: 10.1016/S0140-6736(03)14630-2

8. Ksiazek TG, Erdman D, Goldsmith CS, Zaki SR, Peret T, Emery S, et al. A novel coronavirus associated with severe acute respiratory syndrome. $\mathrm{N} \mathrm{Engl}$ J Med. (2003) 348:1953-66. doi: 10.1056/NEJMoa030781

9. Drosten C, Günther S, Preiser W, van der Werf S, Brodt HR, Becker S, et al. Identification of a novel coronavirus in patients with severe acute respiratory syndrome. N Engl J Med. (2003) 348:1967-76. doi: 10.1056/NEJMoa030747

10. Shi Y, Wang G, Cai XP, Deng JW, Zheng L, Zhu HH, et al. An overview of COVID-19. J Zhejiang Univ Sci B. (2020) 21:343-60. doi: 10.1631/jzus.B2000083

11. Chan JF-W, Yuan S, Kok K-H, To KK-W, Chu H, Yang J, et al. A familial cluster of pneumonia associated with the 2019 novel coronavirus indicating person-to-person transmission: a study of a family cluster. Lancet. (2020) 395:S0140-6736(20)30154-9. doi: 10.1016/S0140-6736(20) 30154-9 go, but it will greatly contribute to the clinical diagnosis of COVID-19.

\section{AUTHOR CONTRIBUTIONS}

JW conceived and designed the study. SL, MZ, XH, HZ, and ML collected the literature. SL drafted the paper. JW, CC, and QL revised the manuscript with input from all coauthors. JW, XZ, and JX provided funding support. $\mathrm{XC}$ and $\mathrm{JZ}$ were the principal investigators for the detection of SARS-CoV-2. All authors read, contributed to, and approved the final manuscript.

\section{FUNDING}

This research was supported by a grant from the Science and Technology Commission of Shanghai (20Y11900700), a grant from the Special Research Fund of Youan Medical Alliance for the Liver and Infectious Diseases (LM202020), a grant from the National Special Research Program of China for Important Infectious Diseases (2018ZX10302103-003), and a grant from the National Natural Science Foundation of China (81672383).

12. Huang C, Wang Y, Li X, Ren L, Zhao J, Hu Y, et al. Clinical features of patients infected with 2019 novel coronavirus in Wuhan, China. Lancet. (2020) 395:497-506. doi: 10.1016/S0140-6736(20)30183-5

13. Assiri A, Al-Tawfiq JA, Al-Rabeeah AA, Al-Rabiah FA, Al-Hajjar S, AlBarrak A, et al. Epidemiological, demographic, and clinical characteristics of 47 cases of Middle East respiratory syndrome coronavirus disease from Saudi Arabia: a descriptive study. Lancet Infect Dis. (2013) 13:75261. doi: 10.1016/S1473-3099(13)70204-4

14. Lee N, Hui D, Wu A, Chan P, Cameron P, Joynt GM, et al. A major outbreak of severe acute respiratory syndrome in Hong Kong. N Engl J Med. (2003) 348:1986-94. doi: 10.1056/NEJMoa030685

15. Dong N, Yang X, Ye L, Chen K,Wai-Chi Chan E, Yang M, et al. Genomic and protein structure modelling analysis depicts the origin and infectivity of 2019$\mathrm{nCoV}$, a new coronavirus which caused a pneumonia outbreak in Wuhan, China. BioRxiv. (2020). doi: 10.1101/2020.01.20.913368

16. Li MY, Li L, Zhang Y, Wang XS. Expression of the SARS-CoV-2 cell receptor gene ACE2 in a wide variety of human tissues. Infect Dis Poverty. (2020) 9:45. doi: 10.1186/s40249-020-00662-x

17. Glowacka I, Bertram S, Müller MA, Allen P, Soilleux E, Pfefferle S, et al. Evidence that TMPRSS2 activates the severe acute respiratory syndrome coronavirus spike protein for membrane fusion and reduces viral control by the humoral immune response. J Virol. (2011) 85:412234. doi: 10.1128/JVI.02232-10

18. Kuhn JH, Li W, Choe H, Farzan M. Angiotensin-converting enzyme 2: a functional receptor for SARS coronavirus. Cell Mol Life Sci. (2004) 61:273843. doi: 10.1007/s00018-004-4242-5

19. Munster VJ, Koopmans M, van Doremalen N, van Riel D, de Wit E. A novel coronavirus emerging in China - key questions for impact assessment. $\mathrm{N} \mathrm{Engl}$ J Med. (2020) 382:692-4. doi: 10.1056/NEJMp2000929

20. Pérez-López B, Mir M. Commercialized diagnostic technologies to combat SARS-CoV2: advantages and disadvantages. Talanta. (2021) 225:121898. doi: 10.1016/j.talanta.2020.121898

21. Giri B, Pandey S, Shrestha R, Pokharel K, Ligler FS, Neupane BB. Review of analytical performance of COVID-19 detection methods. Anal Bioanal Chem. (2021) 413:35-48. doi: 10.1007/s00216-020-02889-x

22. Paul NS, Roberts H, Butany J, Chung T, Gold W, Mehta S, et al. Radiologic pattern of disease in patients with severe acute respiratory syndrome: the Toronto experience. Radiographics. (2004) 24:553-63. doi: 10.1148/rg.242035193 
23. Ajlan AM, Ahyad RA, Jamjoom LG, Alharthy A, Madani TA. Middle East respiratory syndrome coronavirus (MERS-CoV) infection: chest CT findings. AJR Am J Roentgenol. (2014) 203:782-7. doi: 10.2214/AJR.14.13021

24. Song F, Shi N, Shan F, Zhang Z, Shen J, Lu H, et al. Emerging coronavirus 2019-nCoV pneumonia. Radiology. (2020) 295:200274. doi: 10.1148/radiol.2020200274

25. Chung M, Bernheim A, Mei X, Zhang N, Huang M, Zeng X, et al. CT imaging features of 2019 novel coronavirus (2019-nCoV). Radiology. (2020) 295:200230. doi: 10.1148/radiol.2020200230

26. Shi $\mathrm{H}, \mathrm{Han} \mathrm{X}$, Jiang N, Cao Y, Alwalid O, Gu J, et al. Radiological findings from 81 patients with COVID-19 pneumonia in Wuhan, China: a descriptive study. Lancet Infect Dis. (2020) 20:425-34. doi: 10.1016/S1473-3099(20)30086-4

27. Ogimi C, Englund JA, Bradford MC, Qin X, Boeckh M, Waghmare A. Characteristics and outcomes of coronavirus infection in children: the role of viral factors and an immunocompromised state. J Pediatr Infect Dis Soc. (2019) 8:21-8. doi: 10.1093/jpids/pix093

28. Liu F, Zhang Q, Huang C, Shi C, Wang L, Shi N, et al. CT quantification of pneumonia lesions in early days predicts progression to severe illness in a cohort of COVID-19 patients. Theranostics. (2020) 10:561322. doi: $10.7150 /$ thno. 45985

29. Yu Q, Wang Y, Huang S, Liu S, Zhou Z, Zhang S, et al. Multicenter cohort study demonstrates more consolidation in upper lungs on initial CT increases the risk of adverse clinical outcome in COVID-19 patients. Theranostics. (2020) 10:5641-8. doi: 10.7150/thno.46465

30. Zhao W, Zhong Z, Xie X, Yu Q, Liu J. CT scans of patients with 2019 novel coronavirus (COVID-19) pneumonia. Theranostics. (2020) 10:460613. doi: $10.7150 /$ thno. 45016

31. Borghesi A, Maroldi R. COVID-19 outbreak in Italy: experimental chest Xray scoring system for quantifying and monitoring disease progression. Radiol Med. (2020) 125:509-13. doi: 10.1007/s11547-020-01200-3

32. Borakati A, Perera A, Johnson J, Sood T. Diagnostic accuracy of X-ray versus CT in COVID-19: a propensity-matched database study. BMJ Open. (2020) 10:e042946. doi: 10.1136/bmjopen-2020-042946

33. Jacobi A, Chung M, Bernheim A, Eber C. Portable chest X-ray in coronavirus disease-19 (COVID-19): a pictorial review. Clin Imaging. (2020) 64:35-42. doi: 10.1016/j.clinimag.2020.04.001

34. Wong HYF, Lam HYS, Fong AH, Leung ST, Chin TW, Lo CSY, et al. Frequency and distribution of chest radiographic findings in patients positive for COVID-19. Radiology. (2020) 296:E72-8. doi: 10.1148/radiol.2020201160

35. Zhu N, Zhang D, Wang W, Li X, Yang B, Song J, et al. A novel coronavirus from patients with pneumonia in China, 2019. N Engl J Med. (2020) 382:72733. doi: 10.1056/NEJMoa2001017

36. Raj VS, Farag EA, Reusken CB, Lamers MM, Pas SD, Voermans J, et al. Isolation of MERS coronavirus from a dromedary camel, Qatar, 2014. Emerg Infect Dis. (2014) 20:1339-42. doi: 10.3201/eid2008.140663

37. Cotten M, Lam TT, Watson SJ, Palser AL, Petrova V, Grant P, et al. Full-genome deep sequencing and phylogenetic analysis of novel human betacoronavirus. Emerg Infect Dis. (2013) 19:736-42B. doi: 10.3201/eid1905.130057

38. Li B, Si HR, Zhu Y, Yang XL, Anderson DE, Shi ZL, et al. Discovery of bat coronaviruses through surveillance and probe capture-based next-generation sequencing. mSphere. (2020) 5:e00807-19. doi: 10.1128/mSphere.00807-19

39. Carroll D, Daszak P, Wolfe ND, Gao GF, Morel CM, Morzaria S, et al. The global virome project. Science. (2018) 359:872-4. doi: 10.1126/science.aap7463

40. Novel 2019 Coronavirus Genome. Virological. Available online at: http:// virological.org/t/novel-2019-coronavirus-genome/319 (accessed May 22, 2021).

41. Global Initiative on Sharing All Influenza Data. Available online at: https:// www.gisaid.org/ (accessed May 22, 2021).

42. Jin YH, Cai L, Cheng ZS, Cheng H, Deng T, Fan YP, et al. A rapid advice guideline for the diagnosis and treatment of 2019 novel coronavirus (2019-nCoV) infected pneumonia (standard version). Mil Med Res. (2020) 7:4. doi: 10.1186/s40779-020-0233-6

43. Yohe S, Thyagarajan B. Review of clinical next-generation sequencing. Arch Pathol Lab Med. (2017) 141:1544-57. doi: 10.5858/arpa.2016-0501-RA

44. Wang W, Xu Y, Gao R, Lu R, Han K, Wu G, et al. Detection of SARSCoV-2 in different types of clinical specimens. JAMA. (2020) 323:18434. doi: 10.1001/jama.2020.3786
45. Emery SL, Erdman DD, Bowen MD, Newton BR, Winchell JM, Meyer $\mathrm{RF}$, et al. Real-time reverse transcription-polymerase chain reaction assay for SARS-associated coronavirus. Emerg Infect Dis. (2004) 10:3116. doi: 10.3201/eid1002.030759

46. Peiris JS, Chu CM, Cheng VC, Chan KS, Hung IF, Poon LL, et al. Clinical progression and viral load in a community outbreak of coronavirusassociated SARS pneumonia: a prospective study. Lancet. (2003) 361:176772. doi: 10.1016/S0140-6736(03)13412-5

47. General Office of National Health Commission of China. Technical Guide for Laboratory Testing of Pneumonia in a Novel Coronavirus Infection. General Office of National Health Commission of China (2020).

48. SuHong CZM, Jian H, Yu D, Xiao-Chen B, ShengQi W. Development of real time RT-PCR assay for the quantitation of SARS-associated coronavirus. Prog Biochem Biophys. (2004) 31:249-54.

49. Poon LL, Chan KH, Wong OK, Cheung TK, Ng I, Zheng B, et al. Detection of SARS coronavirus in patients with severe acute respiratory syndrome by conventional and real-time quantitative reverse transcription-PCR assays. Clin Chem. (2004) 50:67-72. doi: 10.1373/clinchem.2003.023663

50. Hang CZX, Weiwei G, Chong W, Hualei W, Na F, Tiecheng W, et al. Development of a real-time PCR assay to detect Middle East respiratory syndrome coronavirus. J Pathogen Biol. (2014) 9:673-7. doi: $10.13350 /$ j.cjpb.140801

51. Corman VM, Ölschläger S, Wendtner CM, Drexler JF, Hess M, Drosten C. Performance and clinical validation of the RealStar MERS-CoV Kit for detection of Middle East respiratory syndrome coronavirus RNA. J Clin Virol. (2014) 60:168-71. doi: 10.1016/j.jcv.2014.03.012

52. Hashemzadeh MS, Rasouli R, Zahraei B, Izadi M, Tat M, Saadat SH, et al. Development of dual taqman based one-step rRT-PCR assay panel for rapid and accurate diagnostic test of MERS-CoV: a novel human coronavirus, ahead of Hajj Pilgrimage. Iran Red Crescent Med J. (2016) 18:e23874. doi: $10.5812 /$ ircmj.23874

53. Chu DKW, Pan Y, Cheng SMS, Hui KPY, Krishnan P, Liu Y, et al. Molecular diagnosis of a novel coronavirus (2019-nCoV) causing an outbreak of pneumonia. Clin Chem. (2020) 66:549-55. doi: 10.1093/clinchem/hvaa029

54. FDA. Emergency Use Authorizations. Available online at: https://www.fda. gov/emergency-preparedness-and-response/mcm-legal-regulatory-andpolicy-framework/emergency-use-authorization (accessed May 22, 2021).

55. Rümenapf $T$, Strauss EG, Strauss JH. Subgenomic mRNA of Aura alphavirus is packaged into virions. J Virol. (1994) 68:56-62. doi: 10.1128/JVI.68.1.56-62.1994

56. Simons FA, Vennema H, Rofina JE, Pol JM, Horzinek MC, Rottier PJM, et al. A mRNA PCR for the diagnosis of feline infectious peritonitis. J Virol Methods. (2005) 124:111-6. doi: 10.1016/j.jviromet.2004.11.012

57. Guo Y, Wang K, Zhang Y, Zhang W, Wang L, Liao P. Comparison and analysis of detection performance of six domestic new coronavirus nucleic acid detection reagents. Chongqing Med. (2020) 49:2435-9. doi: 10.3969/j.issn.1671-8348.2020.15.004

58. Ahn DG, Shin HJ, Kim MH, Lee S, Kim HS, Myoung J, et al. Current status of epidemiology, diagnosis, therapeutics, and vaccines for novel coronavirus disease 2019 (COVID-19). J Microbiol Biotechnol. (2020) 30:31324. doi: $10.4014 / \mathrm{jmb} .2003 .03011$

59. Wee SK, Sivalingam SP, Yap EPH. Rapid direct nucleic acid amplification test without RNA extraction for SARS-CoV-2 using a portable PCR thermocycler. Genes. (2020) 11:664. doi: 10.3390/genes11060664

60. Pham XH, Baek A, Kim TH, Lee SH, Rho WY, Chung WJ, et al. Graphene oxide conjugated magnetic beads for RNA extraction. Chem Asian J. (2017) 12:1883-8. doi: 10.1002/asia.201700554

61. Jingbo Zou YZ, Jie Qiao, Xia Li, Jing Zhou, Tingyan Sun, Yiheng Ouyang, Zongyu Zhou, Xiaoyu Wei, Wenguang Tian, Mei Han. Case report on new type coronavirus positive in 2019 in the feces of treated "new crown" patients in Chongqing. Chin J Virol. (2020) 36:165-8. doi: 10.13242/j.cnki.bingduxuebao.003653

62. Conti P, Ronconi G, Caraffa A, Gallenga CE, Ross R, Frydas I, et al. Induction of pro-inflammatory cytokines (IL-1 and IL-6) and lung inflammation by Coronavirus-19 (COVI-19 or SARS-CoV-2): anti-inflammatory strategies. $J$ Biolog Regul Homeost Agents. (2020) 34:327-31. doi: 10.23812/CONTI-E

63. Wuhan Easy diagnosis Biomedicine Co., Ltd. Available online at: http://www. mdeasydiagnosis.com/ (accessed May 22, 2021). 
64. Zhejiang Orient Gene Biotech Co., Ltd. Available online at: http://zjdfjyswzp. yixie8.com/ (accessed May 22, 2021).

65. Promega. Available online at: https://www.promega.com.cn/products/ (accessed May 22, 2021).

66. Shaorui Shi BN, Guo Y, Luo L, Zhang L, Li W, Xian G, et al. Viral nucleic acid test results of multiple biological samples from new coronavirus pneumonia cases. West China Med J. (2020) 35:132-6. doi: 10.7507/1002-0179.202002063

67. Broughton JP, Deng X, Yu G, Fasching CL, Servellita V, Singh J, et al. CRISPRCas12-based detection of SARS-CoV-2. Nat Biotechnol. (2020) 38:8704. doi: 10.1038/s41587-020-0513-4

68. Patchsung M, Jantarug K, Pattama A, Aphicho K, Suraritdechachai $\mathrm{S}$, Meesawat $\mathrm{P}$, et al. Clinical validation of a Cas13-based assay for the detection of SARS-CoV-2 RNA. Nat Biomed Eng. (2020) 4:11409. doi: $10.1038 / \mathrm{s} 41551-020-00603-\mathrm{x}$

69. The Global Fund. Diagnostic Test Kits and Equipments Eligible for Procurement According to Board Decision on Additional Support for Country Responses to COVID-19. Available online at: https://www.theglobalfund. org/media/9629/covid19_diagnosticproducts_list_en.pdf/ (accessed May 22, 2021).

70. Hong TC, Mai QL, Cuong DV, Parida M, Minekawa H, Notomi $\mathrm{T}$, et al. Development and evaluation of a novel loop-mediated isothermal amplification method for rapid detection of severe acute respiratory syndrome coronavirus. J Clin Microbiol. (2004) 42:1956-61. doi: 10.1128/JCM.42.5.1956-1961.2004

71. Kashir J, Yaqinuddin A. Loop mediated isothermal amplification (LAMP) assays as a rapid diagnostic for COVID-19. Med Hypotheses. (2020) 141:109786. doi: 10.1016/j.mehy.2020.109786

72. Rödel J, Egerer R, Suleyman A, Sommer-Schmid B, Baier M, Henke A, et al. Use of the variplex ${ }^{\text {TM }}$ SARS-CoV-2 RT-LAMP as a rapid molecular assay to complement RT-PCR for COVID-19 diagnosis. J Clin Virol. (2020) 132:104616. doi: 10.1016/j.jcv.2020.104616

73. Tworek JA, Khan F, Sekedat MD, Scheidel C, Malani AN. The utility of rapid nucleic acid amplification testing to triage symptomatic patients and to screen asymptomatic preprocedure patients for SARS-CoV-2. Open Forum Infect Dis. (2021) 8:ofaa607. doi: 10.1093/ofid/ofaa607

74. Lopez-Rincon A, Perez-Romero CA, Tonda A, Mendoza-Maldonado L, Claassen E, Garssen J, et al. Design of specific primer sets for the detection of B.1.1.7, B.1.351 and P.1 SARS-CoV-2 variants using deep learning. BioRxiv. (2021). doi: 10.1101/2020.12.29.424715

75. Korukluoglu G, KolukirikM, Bayrakdar F, Ozgumus GG, Altas AB, Cosgun Y, et al. 40 minutes RT-qPCR assay for screening spike N501Y and HV69-70del mutations. BioRxiv. (2021). doi: 10.1101/2021.01.26.428302

76. Fujimoto K, Chan KH, Takeda K, Lo KF, Leung RH, Okamoto T. Sensitive and specific enzyme-linked immunosorbent assay using chemiluminescence for detection of severe acute respiratory syndrome viral infection. J Clin Microbiol. (2008) 46:302-10. doi: 10.1128/JCM.01006-07

77. Sastre P, Dijkman R, Camunas A, Ruiz T, Jebbink MF, van der Hoek L, et al. Differentiation between human coronaviruses NL63 and 229E using a novel double-antibody sandwich enzyme-linked immunosorbent assay based on specific monoclonal antibodies. Clin Vaccine Immunol. (2011) 18:1138. doi: 10.1128/CVI.00355-10

78. Sunwoo HH, Palaniyappan A, Ganguly A, Bhatnagar PK, Das D, El-Kadi AO, et al. Quantitative and sensitive detection of the SARS-CoV spike protein using bispecific monoclonal antibody-based enzyme-linked immunoassay. $J$ Virol Methods. (2013) 187:72-8. doi: 10.1016/j.jviromet.2012.09.006

79. Chen Y, Chan KH, Kang Y, Chen H, Luk HK, Poon RW, et al. A sensitive and specific antigen detection assay for Middle East respiratory syndrome coronavirus. Emerg Microbes Infect. (2015) 4:e26. doi: 10.1038/emi.2015.26

80. Chao He HJ, Yi Xie, Jie Chen, Binwu Ying, Xiaojun Lu,Xingbo Song,Minjin Wang, Yong He, Mei Kang. Discussion on laboratory test path of diagnosis and treatment of new coronavirus pneumonia. Chin J Respir Crit Care Med. (2020) 19:125-7. doi: 10.7507/1671-6205.202002053

81. Xiang F, Wang X, He X, Peng Z, Yang B, Zhang J, et al. Antibody detection and dynamic characteristics in patients with coronavirus disease 2019. Clin Infect Dis. (2020) 71:1930-4. doi: 10.1093/cid/ciaa461
82. Li Z, Yi Y, Luo X, Xiong N, Liu Y, Li S, et al. Development and clinical application of a rapid IgM-IgG combined antibody test for SARS-CoV-2 infection diagnosis. J Med Virol. (2020) 92:1518-24. doi: 10.1002/jmv.25727

83. Lassaunière R, Frische A, Harboe ZB, Nielsen ACY, Fomsgaard A, Krogfelt $\mathrm{KA}$, et al. Evaluation of nine commercial SARS-CoV-2 immunoassays. medRxiv. (2020). doi: 10.1101/2020.04.09.20056325

84. Garcia-Beltran WF, Lam EC, Astudillo MG, Yang D, Miller TE, Feldman J, et al. COVID-19-neutralizing antibodies predict disease severity and survival. Cell. (2021) 184:476-88.e11. doi: 10.1016/j.cell.2020.12.015

85. Yüce M, Filiztekin E, Özkaya KG. COVID-19 diagnosis a review of current methods. Biosens Bioelectron. (2021) 172:112752. doi: 10.1016/j.bios.2020.112752

86. Ehrenfeld M, Tincani A, Andreoli L, Cattalini M, Greenbaum A, Kanduc D, et al. Covid-19 and autoimmunity. Autoimmun Rev. (2020) 19:102597. doi: 10.1016/j.autrev.2020.102597

87. Khamsi R. Rogue antibodies could be driving severe COVID-19. Nature. (2021) 590:29-31. doi: 10.1038/d41586-021-00149-1

88. Bastard P, Rosen LB, Zhang Q, Michailidis E, Hoffmann HH, Zhang $\mathrm{Y}$, et al. Autoantibodies against type I IFNs in patients with lifethreatening COVID-19. Science. (2020) 370:eabd4585. doi: 10.1126/science. abd4585

89. Jamilloux $\mathrm{Y}$, Henry $\mathrm{T}$, Belot $\mathrm{A}$, Viel S, Fauter $\mathrm{M}$, El Jammal $\mathrm{T}$, et al. Should we stimulate or suppress immune responses in COVID19? Cytokine and anti-cytokine interventions. Autoimmun Rev. (2020) 19:102567. doi: 10.1016/j.autrev.2020.102567

90. Chen N, Zhou M, Dong X, Qu J, Gong F, Han Y, et al. Epidemiological and clinical characteristics of 99 cases of 2019 novel coronavirus pneumonia in Wuhan, China: a descriptive study. Lancet. (2020) 395:507-13. doi: 10.1016/S0140-6736(20)30211-7

91. Takahashi T, Ellingson MK, Wong P, Israelow B, Lucas C, Klein J, et al. Sex differences in immune responses that underlie COVID-19 disease outcomes. Nature. (2020) 588:315-20. doi: 10.1038/s41586-0202700-3

92. Mingchao Zhu YZ. Laboratory examination of new coronavirus pneumonia and management of clinical laboratory. J Trop Med. (2020) 20:294-6.

93. Cytokine Storm Detection Scheme in COVID19. Available online at: https://wiki.antpedia.com/ xinxingguanzhuangbingdufeiyanxibaoyinzifengbaojiancefanganllaimple2374441-news (accessed May 22, 2021).

94. Guan WJ, Ni ZY, Hu Y, Liang WH, Ou CQ, He JX, et al. Clinical characteristics of coronavirus disease 2019 in China. N Engl J Med. (2020) 382:170820. doi: 10.1056/NEJMoa2002032

95. Karzai W, Oberhoffer M, Meier-Hellmann A, Reinhart K. Procalcitonin-a new indicator of the systemic response to severe infections. Infection. (1997) 25:329-34. doi: 10.1007/BF01740811

96. Seo G, Lee G, Kim MJ, Baek SH, Choi M, Ku KB, et al. Rapid detection of COVID-19 causative virus (SARS-CoV-2) in human nasopharyngeal swab specimens using field-effect transistor-based biosensor. ACS Nano. (2020) 14:5135-42. doi: 10.1021/acsnano. 0c02823

Conflict of Interest: XC and MZ were employed by the company Zhuhai Livzon Diagnostics Inc.

The remaining authors declare that the research was conducted in the absence of any commercial or financial relationships that could be construed as a potential conflict of interest.

Copyright $\odot 2021 \mathrm{Liu}, \mathrm{Li}$, Chu, Zeng, Liu, He, Zou, Zheng, Corpe, Zhang, Xu and Wang. This is an open-access article distributed under the terms of the Creative Commons Attribution License (CC BY). The use, distribution or reproduction in other forums is permitted, provided the original author(s) and the copyright owner(s) are credited and that the original publication in this journal is cited, in accordance with accepted academic practice. No use, distribution or reproduction is permitted which does not comply with these terms. 


\section{GLOSSARY}

ACE2, angiotensin-converting enzyme II; ALT, alanine aminotransferase; AST, aspartate aminotransferase; CLEIA, chemiluminescence enzyme-linked immunosorbent assay; CoV, coronavirus; COVID-19, coronavirus disease 2019; CRP, C-reactive protein; CT, computed tomography; DPP, dual path platform; DR, detection rate; ELISA, enzyme-linked immunosorbent assay; ESR, erythrocyte sedimentation rate; FET, field-effect transistor; FER, ferritin; GISAID, Global Initiative on Sharing All Influenza Data; GGOs, ground-glass opacities; $\mathrm{HCoV}$, human coronavirus; hscTnI, hypersensitive troponin I; LAMP, loop-mediated isothermal amplification; $\mathrm{LDH}$, lactate dehydrogenase; MERS-CoV, Middle East respiratory syndrome coronavirus; NGS, next-generation sequencing; NPA, negative percent agreement; $\mathrm{N}$ protein, nucleocapsid protein; ORF1ab, open reading frame $1 \mathrm{ab}$; POC, point of care; PCT, procalcitonin; PPA positive percent agreement; PPV, positive predictive value; PGV, ground-glass opacity volume; RdRp, RNAdependent RNA polymerase; rRT-PCR, real-time reverse transcription polymerase chain reaction; SARS-CoV-1, severe acute respiratory syndrome coronavirus 1 ; $S$ protein, spike protein; $\mathrm{SpO}_{2}$, oxygen saturation; TLR, Toll-like receptor; upE, upstream of the E protein; VL, viral load; WHO, World Health Organization. 